TURIZAM

Volume 17 , Issue 2

84-95 (2013)

\title{
The Role and Challenges of Rural Tourism Development in Transition Countries: Montenegro Experiences
}

\author{
Ilija Moric* \\ Received: May 2013 | Accepted: June 2013
}

\begin{abstract}
Rural tourism is widely promoted as an efficient means of counteracting the social, economic and environmental challenges facing rural areas, primarily those associated with the decline of traditional agrarian industries. In line with this, the objective of this paper is to investigate the role and key challenges of rural tourism development in Montenegro as typical transitional economy. Using the extensive literature, available secondary and primary data collected from rural tourism operators, this paper throws light on the main components and issues about current situation in rural areas and rural tourism in Montenegro. Key findings indicate that three key factors of future success should be pulled out, as follows: support from government and international and/or national bodies/organizations, development of new and diversification of present tourist offers in rural areas and enhancement of government policy in the area of entrepreneurship and starting-up of new businesses in rural areas. Regarding practical implications, this paper provide the guidance and ideas for further rural and tourism development in Montenegro.
\end{abstract}

Key words: rural tourism, Montenegro, rural development, transition country, entrepreneurship, rural community.

\section{Introduction}

The first decade of the twenty-first century brought significant strategic shift from mass tourism towards the development of alternative forms of tourism as a response to increasing insecurity generated by dynamic and structural changes in consumer behaviour patterns, international competition, technology development, social and environmental responsibility and other factors. The protection and conservation of natural resources and socio-cultural heritage is now especially considered an essential component of sustainable development (e.g. Cooper, Fletcher, Fyall, Gilbert and Wanhill, 2005; Holloway, 2006; Stojanović, 2006). As a result, there is a greater appeal for sustainable, responsible and balanced regional develop-

* University of Montenegro, Faculty of Tourism and Hotel Management, Stari grad 320, 85330 Kotor, Montenegro, e-mail: imoric@t-com.me. 
ment, particularly in transition countries due to more challenging economic and socio-cultural ambient. In line with this, an increasing academic attention has been paid to the development of rural tourism which is widely promoted as a means of counteracting the social and economic challenges facing rural areas, primarily those associated with the decline of traditional agrarian industries and increased emigration (e.g. Cánoves, Villarino, Priestley, and Blanco, 2004; Nylander and Hall, 2005; Demonja and Ružić, 2OII). From the tourist point of view, rural tourism offer is completely devoted to an individual and his/her needs, together with other selective forms of tourism (e.g. cultural, eco-, MICE, adventure tourism). From the tourist destination point of view, main contributions are related to the general diversification of the rural economy, specialization and creation of new rural tourist products, generation of additional income in family farms, protection of natural resources etc. If we look at it as a whole, rural tourism is considered to be a sustainable, multi-functional activity based on local resources and related traditional agricultural, cultural and natural resources (OECD, I994; EC, 2000; UNWTO, 2002).

On the other side, agricultural sector in Europe is facing dramatic changes, due to different factors such as climatic changes, changed subvention system, environmental policy, tourism development etc (Straaten, 2000). Several instruments and policies are developed by the European Union in order to solve social, economic and environmental problems in the rural areas. According to the guidelines and principles defined in CAP (Common Agricultural Policy), more than 50\% of the European Union's budget used to be transferred to agriculture, but the political support for such percentage is decreasing, and financial support for farms is not as intense as it used to be in the past decades. ${ }^{1}$ Under these circumstances, every farmer's attempt to increase the income on a farm leads to decrease of labour costs and increase in capital investments (new equipment, buildings etc). This certainly leads to unemployment in rural areas. Migration from remote rural areas to centres that could provide better conditions for living and working is also present. The abandoned land is usually hit by the erosion process and decrease in the surface of grassland. Other consequences are empty areas, changed cultural landscape, higher risk from fires and other forms of devastations.

Above mentioned newly constituted circumstances in broader vicinity brought to the situation that Montenegro as a transition country has been constantly exposed to complex conditions for more than two decades in which the things started to go through the most dynamic changes in the area of tourism development and rural development as well. When the socialist system fell apart, it brought to significant changes in the economies of "Ex-Yu" republics. Basic postulates built for more decades of non-market economy were destroyed, thus all economies, regardless of some differences of system nature or market value of some production factors - were marked as - "transitional economies" (Mihailović and Melović, 2OII). Also, our region was comprised by the wind of war, which left horrible consequences on the economies of all "Ex-Yu" republics and on each individual as well. Besides, these consequences are felt strongly and they will be probably present in the distant future. With regards to complex economic and social surrounding, the rural areas are especially fac-

The Common Agricultural Policy (CAP) is a system of European Union agricultural subsidies and programmes. It represented $47 \%$ of the EU's budget, $€ 5$ O billion in 2006. The CAP combines a direct subsidy payment for crops and land which may be cultivated with price support mechanisms, including guaranteed minimum prices, import tariffs and quotas on certain goods from outside the EU. By 2OI3, the share of traditional CAP spending is projected to decrease significantly to $32 \%$, following a decrease in real terms in the current financing period. In contrast, the amounts for the EU's Regional Policy represented I7\% of the EU budget in I988. They will more than double to reach almost $36 \%$ in 2013 . (EU, 2OII). 
ing great number of negative changes, mostly economic, followed by social and ecological. Namely, there are many rural areas which are exposed to continuous processes of depopulation, economic decline and complete marginalization due to the intense process of industrialization, urbanization and electrification. The village is declining and takes away the authentic way of life and overall culture of the village because people as carriers and transmitters of such values are leaving. Further depopulation, with the introduction of new non-agricultural activities and re-routing of mass tourism, cause the rural areas to squeeze traditional farming and rural life.

In the last decade, Montenegro as a tourist destination is experiencing rapid raise in number of tourist arrivals and overnights (Table I). Some negative aspects of Montenegrin tourism are seen in Table 2 and Figure 3, where almost 97\% of tourist overnights is generated in south region ${ }^{2}$. The rest of Montenegro, central ${ }^{3}$ and north ${ }^{4}$ region, generates only $3 \%$ of overnights, which could be considered as problematic in the sense of sustainable and balanced regional development.

Table 1. The tourist arrivals and overnights in Montenegro from 2002 to 2012.

\begin{tabular}{|l|c|c|c|c|c|c|c|c|c|c|}
\hline Arrivals & 2003 & 2004 & 2005 & 2006 & 2007 & 2008 & 2009 & 2010 & 2011 & 2012 \\
\hline Total & 599430 & 703484 & 820457 & 953961 & 1133432 & 1188116 & 1207694 & 1262985 & 1373454 & 1439500 \\
\hline Foreign & 513576 & 604969 & 722466 & 797071 & 984138 & 1031212 & 1044014 & 1087794 & 1201099 & 1264163 \\
\hline Domestic & 85854 & 98515 & 97991 & 156857 & 149294 & 156904 & 163680 & 175191 & 172355 & 175337 \\
\hline Overnights & 2003 & 2004 & 2005 & 2006 & 2007 & 2008 & 2009 & 2010 & 2011 & 2012 \\
\hline Total & 3796266 & 4561094 & 5211847 & 5936270 & 7294530 & 7794741 & 7552006 & 7964893 & 8775171 & 9151236 \\
\hline Foreign & 3270990 & 3998935 & 4641616 & 5026663 & 6443485 & 6966279 & 6695674 & 6977860 & 7818803 & 8143007 \\
\hline Domestic & 525276 & 562159 & 570231 & 909607 & 851045 & 828462 & 856332 & 987033 & 956368 & 1008229 \\
\hline
\end{tabular}

Source: $h t t p: / / w w w . m o n s t a t . m e, 15.06 .2013$.

Table 2. The regional distribution of tourist arrivals and overnights in Montenegro in 2012.

\begin{tabular}{|l|r|r|r|r|}
\hline Regions & \multicolumn{2}{|c|}{ Arrivals } & \% & \multicolumn{1}{c|}{ Overnights } \\
\hline Southern region & 1301141 & 90.39 & 8857878 & 96.79 \\
\hline Central region & 73892 & 5.13 & 160004 & 1.75 \\
\hline Northern region & 64467 & 4.48 & 133354 & 1.46 \\
\hline Total & 1439500 & 100.00 & 9151236 & 100.00 \\
\hline
\end{tabular}

Source: Monstat, 2013, pp. 2-6.

With relation to these arguments, we can formulate the hypothesis that tourism could be promoted as a means of counteracting the social and economic challenges facing rural areas in Montenegro, primarily those associated with the decline of traditional agrarian industries. It is noteworthy that tourism is in many cases an additional activity that provides significant support to the traditional rural economy, made up primarily of agriculture, forestry, crafts and other activities. This paper throws light on this process in Montenegro, setting

2 Southern region consists of 6 municipalities: Herceg Novi, Tivat, Kotor, Budva, Bar and Ulcinj.

3 Central region consists of 4 municipalities: Podgorica, Nikšić, Cetinje and Danilovgrad.

4 Northern region consists of 12 municipalities: Kolašin, Bijelo Polje, Plav, Plužine, Žabljak, Šavnik, Rožaje, Berane, Petnjica, Andrijevica, Pljevlja and Mojkovac. 


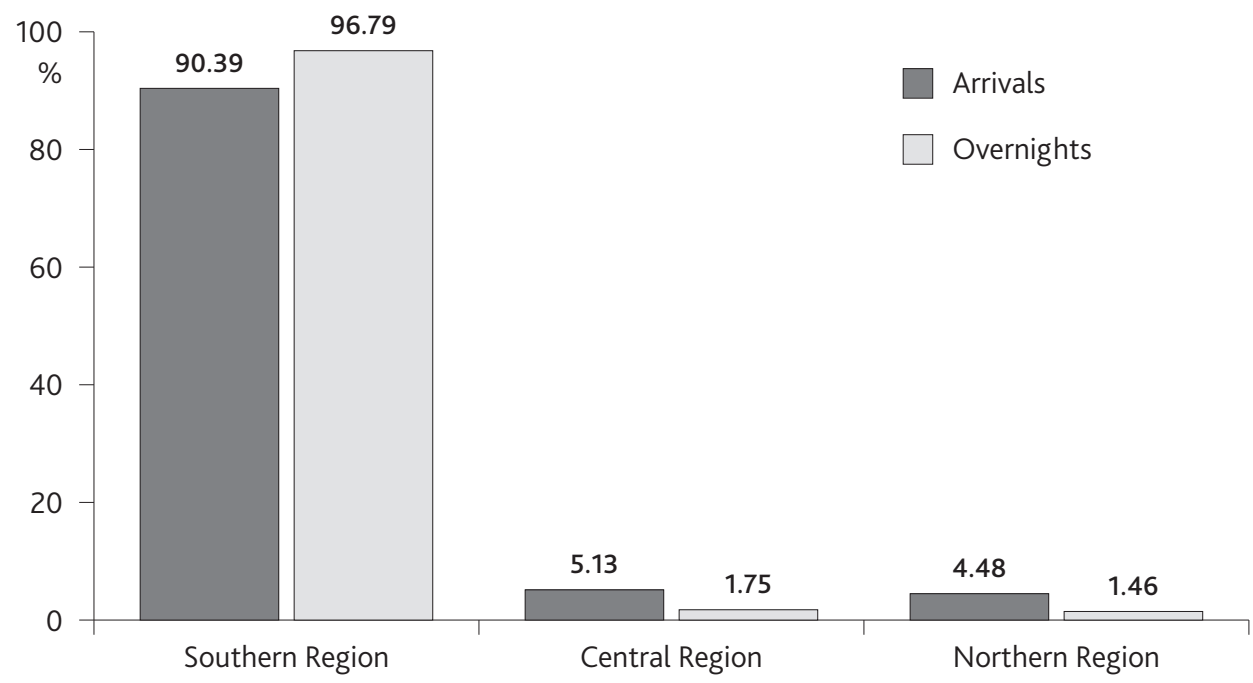

Figure 1. The regional distribution of tourist arrivals and overnights in Montenegro in 2012. Source: Monstat, 2013, pp. 2-6.

out the main components and issues involved and providing guidance and ideas based on the data about current situation in rural areas and rural tourism in Montenegro. With regards to this, the structure of the work consists of five interrelated parts. The reminder of this paper is organized as follows: Section 2 reviews the literature related to the rural tourism, rural development and specifics of Montenegro as a transition country. Section 3 presents the data and methodology. The results are provided and discussed in section 4 . Section 5 concludes and suggests future directions of the research.

\section{Literature review}

The division of rural tourism is very rich and very committed to the characteristics of the area in which tourist activity takes place (Kušen, 2006). Due to this fact, it is necessary to insist on a complex definition of the rural tourism. Rural tourism could be defined as any form of tourism that takes place in rural areas, but this simplification could be quite problematic in the sense of making clear borders between urban resorts situated in rural areas (e.g. golf hotel, spa resort or tourist villa) and authentic rural experience on a tourist farm or in a rural hotel (OECD, I994). "Rural tourism is a term used when rural culture is a key component of the product" (UNWTO, 2004, 9). This concept assumes personalized contact with the tourists and the specific rural experience. Besides, the opportunity to actively participate in certain agricultural activities and other activities, traditions and lifestyle of local residents should be offered, as far as possible. This approach could provide a completely new experience which is almost impossible to achieve in the destination of so-called mass tourism.

According to an extensive literature review and an international survey of rural tourism destinations worldwide, it is possible to pick out a few specifics for the tourist offer in rural destinations. Namely, a tourist offer is extremely fragmented and represented by a large number of micro and small regionally dispersed bidders (Hall, Mitchell and Roberts, 2005). 
Family owned and based on limited resources for further development, these enterprises usually remain small and, in a great extent, rely on a family member, especially females (Opperamann, 1996). Warm welcome and personalized contact are considered to be the most important competitive advantages comparing to other forms of tourism. Typical rural lifestyle is seen as the main attraction, and due to this fact, protection of this intangible element of rural cultural heritage is highly recommended (Cánoves et al., 2004). In any case, preserved rural area with authentic rural life is an essential resource for rural tourism. Rural areas where poor production, smaller quantities and maintaining the traditional way of life represent significant platform for creating innovative tourist products, attractive to tourists from industrialized and suburban areas that have lost the key features of recognition as a rural area. The above mentioned is very important for Montenegro and its rural areas of exceptional natural beauty and rich culture and tradition.

On the other hand, there is also a great number of risk factors that can affect the development of rural tourism, such as:

- Great lack of inconsistency with regards to the quality of services provided and they can vary to a greater or lesser extent (Meyer-Chec, 2005);

- Holders of such positions are limited with staff and finances, which directs them to join forces for more efficient implementation of destination management and marketing programs (Mitchell and Hall, 2005):

- Lack of understanding and/or misunderstanding of the concept of the rural tourism, coupled with the wrong initial assumptions about the simple and easy generation market, income and employment (Sharpley, 2002);

- Non-compliance with the development objectives of local governments and development agencies, and as a result of inadequate communication, lack of confidence, and lack of shared vision of development (Nylander and Hall, 2005);

- Lack of planning for further development and limited use of marketing concept as a business philosophy that leads to the lack of information about the tourists' needs and desires (Clarke, 2005);

- Lack of funds for starting and/or continuation of business as a result of insufficient understanding and support from the state, banking and other financial institutions, especially in transition countries (Demonja and Ružić, 2OII);

- Lack of information on the possibilities and opportunities for further development of tourism, leading to disconnection of villages in a unique tourist product and lack of support of local, regional and governmental entities (Sharpley, 2OO2);

However, it is noteworthy that in many cases rural tourism is an additional, multifunctional activity, complimentary to traditional agriculture which significantly contributes to diversification of traditional rural economy, improves the socio-cultural ambient and provides protection of natural resources in rural areas.

\section{Methodology}

Using the extensive literature, available secondary data from government bodies (e.g. Ministry of Agriculture and Rural Development, Ministry of Sustainable Development and Tourism, Monstat) and relevant international organisations (UNWTO, WTTC) and primary 
data $^{5}$ collected from rural tourism operators in Montenegro, this paper investigates the status quo and factors that affect the rural development and rural tourism development in Montenegro. Followed by qualitative analysis, these factors are analyses in details in order to provide the ideas and guidelines for the future development.

\section{Research results}

\section{The key challenges in rural development in Montenegro}

According to the Monstat (2OII), 40\% of the population lives in the countryside in Montenegro, and there are about 60 ooo rural households, which is about I/3 of overall number of households. Food production and agriculture have an important role in the economic development of Montenegro, generating more than 8\% of total GDP in 2OIO (Monstat, 2OII) Agricultural area in Montenegro covers 38\% of the total surface area, agricultural land resources with a total area of 5I8 067 ha or about 0.84 ha per capita, places Montenegro amongst the leading countries in Europe (Monstat, 2OII). The political and economic changes in Montenegro in the late I980s and at the beginning of I990s, according to statistical data did not result in a fall in production, a characteristics of several other countries going through the transition processes. In the period 1999-2003 growth in total agricultural production was achieved, on average annual rate of $+2.8 \%$ (MAFWM, 2006). In spite of the above mentioned facts, Montenegro is a net importer of agro-food products, due to its unexploited production potentials.

Rural areas in Montenegro have benefited from the government policy of increased financial and technical support, created in 2006, when new Agriculture and Rural Development Strategy was defined. Key measures were focused on the higher financial support for different kinds of farming and crops. Also, crucial change was done by involving the concept of rural development instead of old model of development which defined agriculture as only or main economic activity in rural areas. In other words, the key element in reform of agricultural policy, identified in the Strategy, is the gradual building of a system of integrated rural development policy.

Key challenges of agricultural sector in Montenegro that could be identified as quite critical for the future rural development are the following ones (MAFWM, 2006): (I) Negative demographic movements (moderate depopulation of the rural areas and parallel demographic ageing) in rural areas ${ }^{6}$; (2) Low productivity in agriculture (low technical level of agricultural production concentrated on family farms); (3) Underdeveloped agro-food industry with inadequate technical equipment, and as a consequence, relatively high prices of agricultural products; (4) Insufficient budgetary support (budgetary support for agriculture has

5 The primary data are extracted from the survey conducted in the period from February to the end of May in 2013. The main objective of the survey is to obtain representative view and data regarding rural tourism operators in Montenegro. The questionnaire contains 57 questions. The survey was conducted via post and e-mail. The time allocated for operators to fill the questionnaire was not limited but it took approximately 30 minutes. The number of identified rural tourism operators is 107 , and 94 (or $87.85 \%$ ) of them have answered to the questionnaires.

6 Moreover, this problem greatly impacts the level of entrepreneurship in rural areas, due to migration of the most educated and skilled people out of rural areas. Small and micro entrepreneurs are seen as a force in rural and community development, but still this segment faces with several challenges, such as: lack of adequate sources of capital for investments, lack of knowledge and skills among rural entrepreneurs, lack of opportunities for employment and education, poverty etc. 
a growing tendency but it is slower than the growth of the total budget in Montenegro); (5) High rate of unemployment, weak infrastructure and few social services; (6) Problematic (relatively small) sizes of farms (average farm size is 4.6 ha, and more than $50 \%$ of farms are smaller than I ha); (7) Lack of education and training; (8) Extension services with small number of employees and limited potential for efficient work; (9) Limited credit and financing opportunities via banks, but relatively adequate financing opportunities via international programmes such as $\mathrm{MIDAS}^{7}, \mathrm{OAPD}^{8}$ or national financing body IRF ${ }^{9}$.

In the context of agriculture, limited increase has been achieved in the last decade, although there were very stimulating measures for different forms of productions. This increase is between 2-3\% in the period 2OOI-2006, but after that, there was a decrease of I\% in the period 2006-2OIO (Monstat, 2006, 95; Monstat, 2OII, IO3). On the other side, there are still quite serious challenges regarding agricultural land policy, tax policy, distribution and sale, and undeveloped connection with tourism sector. Besides that, the situation in the north of Montenegro, which is characterized by hilly and mountainous terrain, sharp winters, short summers and weak infrastructure, is quite problematic.

\section{The status quo of the rural tourism in Montenegro}

The high priority given to tourism (and agriculture, as well) as an economic activity of strategic importance in several national development strategies and policies in Montenegro, generated a rapid growth in tourist arrivals, reaching the number of arrivals from the end of 80's, but still highly concentrated in the destinations by the sea (Herceg Novi, Budva, Tivat, Kotor, Bar and Ulcinj) and in just a few destinations inland (Kolašin and Žabljak). Rural areas didn't benefit much from tourism, apart from the destinations that are close to the capital of Podgorica (in the area of Skadar Lake) and areas and villages near the Adriatic coast. The rural tourism sector in Montenegro is represented by more than Ioo businesses, mostly family owned and developed almost without any or with very little institutional support. However, the activities of domestic and foreign development agencies have to be mentioned $\left(\mathrm{GTZ}^{10}, \mathrm{CSTI}^{11}, \mathrm{SNV}^{12}\right.$ etc.) regarding the development of seven thematic trails (Wine Trail, Old Montenegro Trail, Cheese Trail, Honey Trail and Tales, Via Dinarica, Olive Trail, Ethno-gastronomic Trail), with more than IOO $^{13}$ businesses offering visits, domestic food, drinks, souvenirs and other services or products.

Apart from this, in the sense of rural tourism product, two quite important projects of National Tourism Organisation (NTO) and foreign strategic partners (e.g. GTZ-German Organization for Technical Cooperation) could be mentioned. The "Wilderness Hiking \& Biking" project was initiated in 2007 and included in the national "Tourism Development

\footnotetext{
Montenegro Institutional Development and Agriculture Strengthening (MIDAS).

13 During research IO7 rural tourism operators were indentified, although the number of them is constantly changing, due to relatively simple entrance on the tourism market. Almost all of them (99\%) are small or micro businesses, family owned.
} 
Table 3. The number and structure of rural tourism operators in Montenegro

\begin{tabular}{|l|r|r|}
\hline Forms of Rural Tourism Product & $\begin{array}{c}\text { Number of rural } \\
\text { tourism operators }\end{array}$ & $\%$ \\
\hline Ethno village/eco lodge & 21 & 19.63 \\
\hline Tourist farm & 7 & 6.54 \\
\hline Ethno-gastronomic trail (Skadar Lake) & 14 & 13.08 \\
\hline Honey trail and tales & 8 & 7.48 \\
\hline Tourist cheese farm & 3 & 2.80 \\
\hline Olive farm (Olive trail of Montenegro) & 12 & 11.21 \\
\hline Tourist organic farm & 4 & 3.74 \\
\hline Winery (Wine trail of Montenegro) & 38 & 35.51 \\
\hline Total & 107 & 100.00 \\
\hline
\end{tabular}

Source: Author

* Eco lodge in Montenegro is a small, economically self-sustaining luxury accommodation facility with 7 to 50 spacious guestrooms (15 to 100 Beds), en-suite bathrooms- that provides its guests not only with upscale amenities but most importantly, with a special quality of nature interpretive experiences. Eco lodge accommodation facilities are located either inside National Parks or overlooking National Parks. (See more in: Ministry of Tourism E GTZ (2009) Montenegro: "Wild Beauty" accommodation development handbook).

Strategy till 2O2O". On the basis of "Montenegro Wilderness Biking \& Hiking” concept, numerous new accommodations and tour operators specialized in hiking and biking tourism opened up in the hinterland, and strengthened the local economy by providing guests with local products. At the same time new sources of income are being developed and marketed. For example, the first $2 \mathrm{O}$ accommodations are successfully specialized in cycling holidays ("Bed $\prec$ Bike Montenegro"). The implemented measures have strengthened the economic power and counteracted rural migration in Montenegro. Due to these activities, in 2OIO, the National Parks and the North of Montenegro recorded a considerable growth in guest numbers and overnight stays, as well as a prolonged tourist season.

Rural tourism encompasses a great number of activities that take place in rural areas, in protected areas, e.g. national parks, or in wilderness of many Montenegrin mountains and hills. This potential is partly valorised through rural tourism operators situated in the central and northern region of Montenegro (Figure 2). Positive characteristic of the rural tourism is the relatively convenient regional distribution considering the need for balanced regional and sustainable development. More than 6I\% of rural tourism businesses in central and northern region represent an important base for current and further development and valorisation of rich cultural and natural heritage of rural areas in Montenegro. Wilderness areas have become very popular destinations, especially where these are untouched until today, and where the appeal of solitude and communing with nature is most common.

In this sense, rural areas have an opportunity if they can offer a diverse product. But diversity can be considered as a weakness in the case on Montenegro. First of all, lack of product specialization is seen as a considerable disadvantage in a situation where the destination needs a strong drawing power to encourage tourists to come and stay. Hence, every rural destination requires a different or unique attraction to motivate the tourists to come. Finally, intense competition, whether rural or urban, domestic or international destinations, makes this strategic option more desirable among the public and private sector involved in the rural tourism development. 


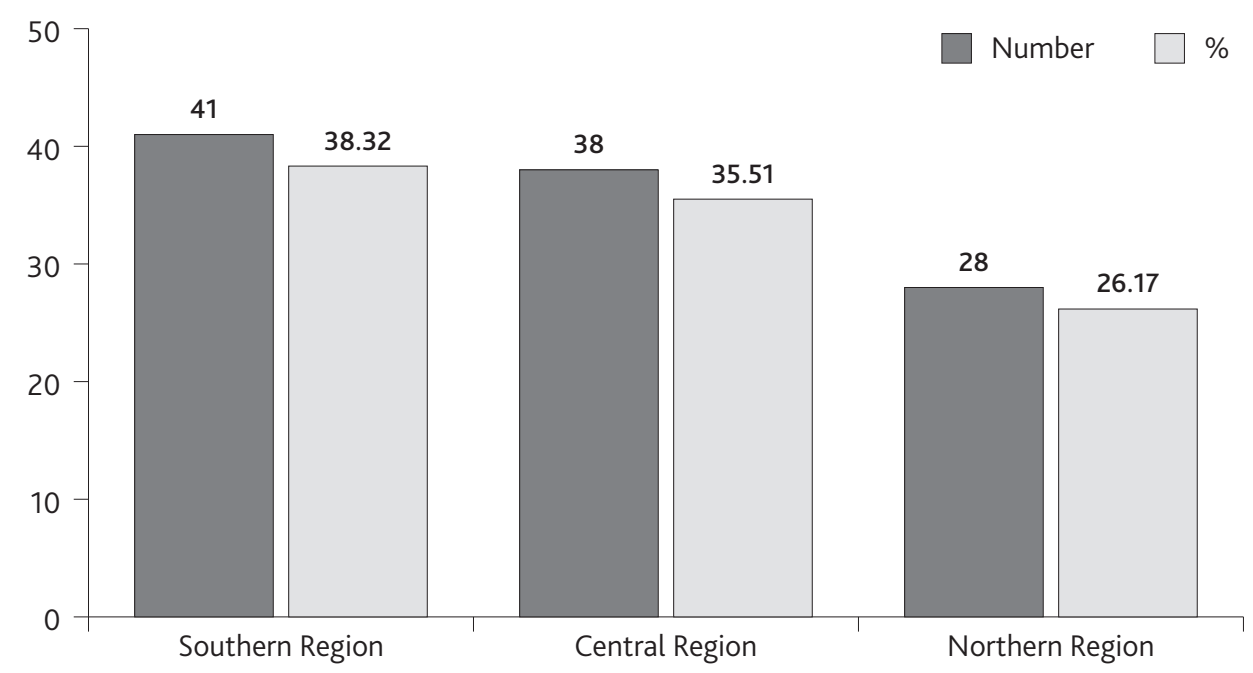

Figure 2. The regional distribution of rural tourism operators in Montenegro

Source: Author

\section{Discussion of the results}

New forms of tourism, such as rural tourism, with all its types and varieties, require many micro and small-scale businesses, family-owned, dispersed and located in rural areas. In this way the economic effects of tourism rest and spread inside the local community, the multiplier is increased, and leakages of tourism income are decreased compared to other types of tourism destinations. Rural tourism obviously generates new employment opportunities and helps to sustain the existing business and creates the new ones. Hence, the key role of rural tourism in rural development may be seen in diversification of economic activities and income in rural regions. Apart from this, protection and preservation of cultural heritage in rural areas, better opportunities for women and disabled people, protection of the environment and biodiversity, etc. are very important. By achieving these tasks, tourism could help the process of rural development in Montenegro, mentioned in the first parts of the paper, and which is consisted of following themes: (I) improving agricultural competitiveness; (2) improving the environment and supporting land management and (3) improving the quality of life and diversifying the economy in rural areas. Accordingly, our hypothesis that tourism could be promoted as a means of counteracting the social and economic challenges facing rural areas in Montenegro is confirmed.

Apart from that, there are relevant academic papers that refer to the need of connecting the concept of sustainable tourism with the need for sound rural development (Sharpley, 20O3; Mitchell and Hall, 2005). Tourism development has to take the protection of landscape and nature as a prerequisite for every type of development, as well (Straaten, 2000). The joint development of agriculture and tourism is of particular importance for Montenegro. A wide range of high quality domestic products could enrich the tourist offer. Tourism can be a powerful generator in the development of agriculture through affirmation of the national cuisine and specific products of Montenegro. On the other side, agriculture offers opportunities for recreation, holidays and the development of specific sporting activities (MAFWM, 2006). 


\section{Conclusion}

Reforms in agriculture and rural development policy are inevitable, especially in terms of the forthcoming integration processes (accession to the EU). Amongst the perspective economy sectors, tourism should be emphasized, since contemporary trends in tourism markets indicate potential for further growth. Tourism could be considered as a means of counteracting of the social and economic challenges facing rural areas, primarily those associated with the decline of traditional agrarian industries. A special role of rural tourism is identified in generating new jobs and additional incomes at farms.

In the sense of the role and potentials of rural tourism, the future of rural areas in Montenegro and their development will be determined by three main factors: First- the support of government and other international and/or national bodies/organizations, whose main aim is to keep and attract people, especially young and educated people in rural areas by ensuring adequate living conditions (e.g. infrastructure development, social services development, protection and preservation of cultural and natural heritage etc). Second - development of new and diversification of present tourism offers in rural areas, based on market research and needs and wishes of modern tourists, and their better connection with other sectors of tourism industry in the country. Third - improvement of government policy in the sector of entrepreneurship and starting-up of new (tourist) businesses in rural areas.

It is possible to raise the living standard of people in rural areas in Montenegro based upon tradition and a new role for agriculture and its connection to other sectors, especially tourism. Undoubtedly, further research is necessary to determine the extent to which the rural tourism could improve the living conditions in rural areas but, nevertheless, this paper has contributed to a broader understanding of the phenomenon of rural tourism and its role in rural development in Montenegro.

\section{References}

Cánoves, G., Villarino, M., Priestley, G.K. and Blanco, A. (2004). Rural Tourism in Spain: An Analysis of Recent Evolution. Geoforum 35, 755-769.

Clarke, J. (2005). Effective Marketing for Rural Tourism, in Hall, D., Kirkpatrick, I. and Mitchell, M. (Ed.), Rural Tourism and Sustainable Business, Clevedon, Channel View Publications, 87-IO2.

Cooper, C., Fletcher J., Fyall A., Gilbert D. and Wanhill S. (2005). Tourism: Principles and Practice, Third edition, Pearson Education Limited, Harlow.

Dahles, H. (2000). Tourism, Small Enterprises and Community Development, in D. Hall and G. Richards (Ed.), Tourism and Sustainable Community Development,: Routledge, London, I54-I69.

Demonja, D. and Ružić, P. (2OII), Rural Tourism in Croatia with Croatian Case Studies of Good Practice and European Experiences, Meridijani, Zagreb.

European Commission (2000). Towards quality rural tourism: Integrated Quality Management (IQM) of Rural Tourist Destinations, Brussels: Enterprise Directorate-General Tourism Unit.

European Commission, Agriculture and Rural Development (2OII). The Common Agricultural Policy Explained, KF-8I-O8-237-EN-C, Brussels: EU. 
European Union, Directorate-General for Agriculture and Rural Development (2OII). Rural Development in the European Union: Statistical and Economic Information, Report 2OII, Brussels.

Gilbert, D. (1989). Rural Tourism and Marketing: Synthesis and New Ways of Working. Tourism Management, 39-50.

Hall D., Mitchell, M. and Roberts, L. (2005). Tourism and the Countryside: Dynamic Relationship, in Hall D., Roberts, L. and Mitchell, M. (Ed.) New Directions in Rural Tourism, Ashgate, Aldershot, 3-I8.

Holloway, J., C. and Taylor, N. (2006). The Business of Tourism, Seventh edition, Prentice Hall, Harlow.

Kušen, E. (2006). Rural Tourism, in S. Marković (Ed.) Croatian Tourism: Blue, White, Green, Scientific Edition, The Book No. 3, Institute for Tourism, Zagreb, I67-I90.

MAFWM, Republic of Montenegro (2006). Montenegro's Agriculture and European Union: Agriculture and Rural Development Strategy, Ministry of Agriculture, Forestry and Water Management, Podgorica.

Meyer-Cech, K. (2005). Regional Cooperation in Rural Tourism Trails, in Hall, D., Kirkpatrick, I. and Mitchell, M. (Ed.) Rural Tourism and Sustainable Business, Clevedon, Channel View Publications, I37-I48.

Mihailović, B. and Melović, B. (2OII). Entreprise Branding in the Transitional Economy, International conference: Contemporary issues in economics, business and management, Kragujevac, 2OII, 233-245.

Mihailović, B. (2OII). Marketing in Tourism: Principles for Management, CID, Podgorica.

Mihailović, B. and Moric, I. (2OI2). The Role of Marketing Philosophy in Rural Tourism Development. Tourism and Hospitality Management I8 (2), 267-279.

Ministry of Tourism \& GTZ (2009). Montenegro: "Wild Beauty" accommodation development handbook.

Mitchell, M. and Hall D. (2005). Rural Tourism as Sustainable Business: Key Themes and Issues, in Hall, D., Kirkpatrick, I. and Mitchell, M. (Ed.) Rural Tourism and Sustainable Business, Channel View Publications, Clevedon, 3-I6.

Monstat (2006), Statistical Yearbook 2006, Montenegro Statistical Office - Monstat, Podgorica.

Monstat (2OII), Statistical Yearbook 2OII, Montenegro Statistical Office - Monstat, Podgorica.

Monstat (2OI3), Tourist Arrivals and Overnights in Montenegro in 2OI2, Montenegro Statistical Office - Monstat, Podgorica.

Nylander, M. and Hall, M. (2005). Rural Tourism Policy: European Perspectives, in C. Cooper, C. M. Hall, and D. Timothy (Ed.), Rural Tourism and Sustainable Business, Channel View Publications, Clevedon, I7-4O.

OECD, (I994) Tourism Strategies and Rural Development, General Distribution, OECD / GD (94) 49, OI3927, Paris.

Oppermann, M. (1996). Rural Tourism in Southern Germany, Annals of Tourism Research, Vol. 23, No. I, 86-IO2.

Sharpley, R. (20O2). Rural Tourism and the Challenge of Tourism Diversification: The Case of Cyprus". Tourism Management 23, 233-244.

Stojanović, V., (2006). Sustainable Development of Tourism and Environment, University of Novi Sad, PMF, Department for Geography, Tourism and Hospitality, Novi Sad. 
Straaten, J. (2000). Can Sustainable Tourism Positively Influence Rural Regions?, in D. Hall and G. Richards (Ed.), Tourism and Sustainable Community Development, Routledge, London, 22I-232.

UNWTO (2004). Rural Tourism in Europe: Experiences, Development and Perspectives, Madrid: UNWTO. 